REVIEW OF HISTORICAL SCIENCES 2018, VOL. XVII, NO. 3

http://dx.doi.org/10.18778/1644-857X.17.03.05

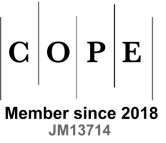

WiTOLD FILIPCZAK

UNIVERSITY OF LODZ*

\title{
Sejmiks in the Land of Liw 1780-1786
}

Summary. The article concerns sejmiks in the land of Liw, which was located in the voivodship of Mazovia. In the years 1780-1786 the noblemen who took part in the debates in Liw elected their envoys and resolved issues connected with self-government. The article discusses preparations for the sejmiks, their course and resolutions adopted there. The land of Liw was dominated by the royalist party, whose main representatives belonged to the Cieszkowski and Cieciszowski families. The iudex terrestris of Liw, Ignacy Cieciszowski, who had been elected an envoy to the Sejm for three times in the years 1780-1786, was the most active parliamentary member. His status was influenced by the support of his brother, Adam, who was in charge of Stanisław August's private chancellery in the years 1780-1783. The connections between leaders of the local nobility and the royalist party did not have a major impact on the content of instructions for envoys, but they could be seen in the activity of the representatives of Liw in the parliament.

Keywords: the land of Liw, sejmiks, parliamentarism, Mazovia in the $18^{\text {th }}$ century.

Whe territory of the land of Liw which was located in the south-eastern part of Mazovia (bordering on Podlachia) was rather small in comparison with other lands in the same voivodship. According to the Atlas Historyczny Polski [Historical Atlas of Poland] its size was $1038 \mathrm{~km}^{2}$, which made it the eight land out of ten. Also, it was one of the two lands (like the land of Wyszogród) that was not subdivided into counties ${ }^{1}$. In terms of prestige, the land of Liw held the $9^{\text {th }}$ position in the hierarchy of the voivodship. It was preceded by the land of Rozan, and followed by

* Faculty of Philosophy and History, Institute of History, Department of Modern History / Wydział Filozoficzno-Historyczny, Instytut Historii, Katedra Historii Nowożytnej, e-mail: dwf@widzew.net.

${ }^{1}$ Mazowsze $w$ drugiej połowie XVI wieku (Atlas historyczny Polski), part 2, ed. W. Pałucki, Warszawa 1973, pp. 59-60. 
the land of Nur'. The highest local office was that of the castellan of Liw. According to the hierarchy established during the Sejm in $1767 / 1768$, this particular office was of a rather low rank. It closed the list of the senatorial offices in the voivodship of Mazovia. It held the $7^{\text {th }}$ position from the end on the list of minor castellans' offices (the castellan of Liw was inferior in rank to that of Ciechanów, and superior to that of Słońsk) ${ }^{3}$. Despite its rather insignificant status, the land of Liw attracted considerable attention of the historians. Anna Sucheni-Grabowska wrote an article about the sejmiks in $16^{\text {th }}$ and $17^{\text {th }}$ centuries ${ }^{4}$. Marek Wagner dealt with the way the sejmiks operated in the reign of Jan III Sobieski ${ }^{5}$. Mirosław Roguski discussed the participation of noblemen of modest means in public gatherings held in the land of Liw in 1765-1795. Leszek Zalewski authored popular texts about the land of Liw and the local members of nobility ${ }^{7}$. The sejmiks, the political life and the issues connected with the political system were the subject of research concerning the whole of Mazovia (by Józef A. Gierowski, Jolanta Choińska-Mika, Adam Moniuszko, Anna and Maciej Pieńkowski, Jan Dzieggielewski and Jerzy Urwanowicz) ${ }^{8}$. The course of Mazovian sejmiks (including the ones held in Liw) was discussed as a result of

${ }^{2}$ J.A. Gierowski, Sejmik generalny księstwa mazowieckiego na tle ustroju sejmikowego Mazowsza, Wrocław 1948, p. 27.

${ }^{3}$ Volumina legum [hereinafter: Vol. leg.], vol. VII, ed. J. Ohryzko, Petersburg 1860, p. 292. Porzadek Senatus, et Ministerii.

${ }^{4}$ A. Sucheni-Grabowska, O sejmiku ziemi liwskiej 1542-1695, [in:] Między Wschodem a Zachodem. Rzeczpospolita XVI-XVIII w. Studia ofiarowane Zbigniewowi Wójcikowi $w$ siedemdziesiata rocznice urodzin, ed. T. Chynczewska-Hennel et al., Warszawa 1993, pp. 29-38.

${ }^{5}$ M. Wagner, Sejmik ziemi liwskiej $w$ dobie Jana III Sobieskiego (1674-1696). Zarys problematyki, [in:] Po unii - sejmiki szlacheckie w Rzeczypospolitej XVI-XVIII wieku, eds H. Lulewicz, M. Wagner, Siedlce 2013, pp. 253-262.

${ }^{6}$ M. Roguski, Udziat drobnej szlachty $w$ sejmikach, konfederacjach i zgromadzeniach ziemi liwskiej w latach 1765-1795, [in:] ibidem, pp. 357-391.

${ }^{7}$ L. Zalewski, Szlachta ziemi liwskiej. Sejmiki, urzędy, herbarz, Warszawa 2005; idem, Ziemia liwska, ludzie, miejscowości, wydarzenia, Warszawa 2002.

${ }^{8}$ J.A. Gierowski, op. cit.; J. Choińska-Mika, Sejmiki mazowieckie $w$ dobie Wazów, Warszawa 1998; eadem, Mazowiecki parlamentaryzm XVI-XVIII wieku, [in:] Dzieje Mazowsza lata 1527-1794, vol. II, ed. J. Tyszkiewicz, Pułtusk 2015, pp. 115-165; A. Moniuszko, Mazowieckie sady ziemskie (1588-1648). Organizacja - funkcjonowanie-postępowanie, Warszawa 2013;A.Pieńkowska, M.A.Pieńkowski, Sejmiki mazowieckie wobec problemów wewnętrznych Rzeczypospolitej $w$ latach 1661-1665, Oświęcim 2015; J. Dzięgielewski, Życie polityczne na Mazowszu od schyłku XV do połowy XVII wieku, [in:] Dzieje Mazowsza..., vol. II, pp. 29-113; J. Urwanowicz, Polityczna aktywność szlachty mazowieckiej w latach 1669-1793, [in:] ibidem, pp. 539-599. 
research on particular political campaigns, e.g. in the monographs on particular sejms. The course of the sejmiks in the second half of the $18^{\text {th }}$ century was analysed by Maria Czeppe (the years 1759-1763), Tomasz Szwaciński (pre-convocation sejmiks 1764), Dorota Dukwicz (1773), Witold Filipczak (1778), Adam Danilczyk (1786), Jerzy Michalski (1788), Zofia Zielińska (1790) and Wojciech Szczygielski (1792) ${ }^{9}$.

The year 1780 proved to be a breakthrough for the sejmik activities in the land of Liw. After the death of head of Stanisław August's private chancellery, that is, Crown Grand Secretary Jacek Ogrodzki on May 15, 1780, his post in the king's private chancellery was taken over by Adam Cieciszowski, the venator of $\mathrm{Liw}^{10}$. He was connected with the land of Liw not only through his office there (at the end of May 1780 he was promoted to the rank of the Crown Grand Notary) ${ }^{11}$. His family played an important part in the sejmiks of Liw. Adam's bother, Ignacy Cieciszowski (both were the sons of Dominik, the castellan of Liw), was promoted to the rank of iudex terrestris of Liw in 1773 (he had earlier received the office of the venator in 1765, and in 1768 that of the pincerna of Liw) ${ }^{12}$. On July 15, 1776 I. Cieciszowski was elected the envoy of Liw, and the Sejm that he took part in became a great success for the royalist

${ }^{9}$ M. Czeppe, Kamaryla Pana z Dukli. Kształtowanie się obozu politycznego Jerzego Augusta Mniszcha 1750-1763, Warszawa 1998, pp. 178-183; T. Szwaciński, Sejmiki poselskie przed konwokacja 1764 r., 'Kwartalnik Historyczny' 2006, vol. CXIII, No. 1, pp. 38-39; D. Dukwicz, Rosja wobec sejmu rozbiorowego warszawskiego (1772-1775), Warszawa 2015, pp. 171-172; W. Filipczak, Sejm 1778 roku, Warszawa 2000, pp. 69-74; A. Danilczyk, Wkregu afery Dogrumowej. Sejm 1786 roku, Warszawa 2010, pp. 88-89; J. Michalski, Sejmiki poselskie 1788 roku, 'Przegląd Historyczny' 1960, vol. LI, issue 2, pp. 350-351; Z. Zielińska, Sejmiki 8 lutego 1790 - pierwsze referendum na temat dokonań sejmu, 'Wiek Oświecenia' 1993, vol. IX, pp. 121-122; eadem, 'O sukcesyi tronu w Polszcze' 1787-1790, Warszawa 1991, p. 210, 218; W. Szczygielski, Referendum trzeciomajowe. Sejmiki lutowe 1792 roku, Łódź 1994, pp. 143-169.

${ }^{10}$ M. Rymszyna, Gabinet Stanisława Augusta, Warszawa 1962, pp. 114-115; Urzędnicy centralni i nadworni Polski XIV-XVIII wieku. Spisy, ed. A. Gąsiorowski, Kórnik 1992, p. 150; W. Filipczak, Życie sejmikowe prowincji wielkopolskiej 17801786, Łódź 2012, p. 51. A. Cieciszowski was nominated for the following offices in the land of Liw: treasurer (1765), minor tribunus (1768) and venator (1773). See M. Danilewiczowa, Cieciszowski Adam, [in:] Polski słownik biograficzny [hereinafter: $P S B$ ], vol. IV, Kraków 1938, p. 37.

${ }^{11}$ Urzędnicy centralni..., p. 100; W. Filipczak, Życie sejmikowe..., p. 52.

${ }^{12}$ M. Danilewiczowa, Cieciszowski Ignacy, [in:] PSB, vol. IV, p. 38; M. Roguski, op. cit., pp. 377-378. The third son of castellan D. Cieciszowski was bishop Kacper Cieciszowski. 
party $^{13}$. At the sejmik on August 17, 1778 opened by Krzysztof Cieciszowski, the castellan of Liw, and run by I. Cieciszowski, J. Ogrodzki and A. Cieciszowski became the envoys representing $\mathrm{Liw}^{14}$. The head of Stanisław August's private chancellery was only too willing to make use of the connections of his close colleague from the land of Liw. A. Cieciszowski's promotion to the role of one of the most influential persons in the sejmik affairs at the court was bound to influence the position of the royalists in the land of Liw. It is worth noting that 'Warsaw' was closely supervising the sejmiks in the Mazovian voivodship in the second half of the seventies in the $18^{\text {th }}$ century ${ }^{15}$.

In the analysed period the first pre-sejm sejmik was meant to take place on August 21 in accordance with the king's universal dated May 22, $1780^{16}$. The court was not worried about the result of the pre-sejm sejmik of Liw; there is no information about preparations for this event in the domestic correspondence between Stanisław August and his ministers. The letters, however, contain much information about court cases which involved influential people from the land of Liw. I am going to discuss them because they shed light on the relations between people from this milieu.

At the end of May 1780 Kazimierz Krasiński, the crown castrametator, wrote to the king that as the custodian of his wife's children (she was Elżbieta née Potocka, widowed by Michał

${ }^{13}$ Instruction for envoys, Liw, July 15, 1776, Archiwum Główne Akt Dawnych w Warszawie / The Central Archives of Historical Records in Warsaw [hereinafter: AGAD], Zbiór Popielów / The Popiel Collection [hereinafter: ZP] ref. code 125, sheet 89; L. Zalewski, Szlachta ziemi..., p. 52. For the sejm in 1776 see J. Michalski, Sejm w czasach panowania Stanisława Augusta, [in:] Historia sejmu polskiego, vol. I, ed. J. Michalski, Warszawa 1984, pp. 375-377; W. Stanek, Konfederacja sejmowa z 1776 roku - narzedzie dworskiego zamachu stanu, 'Acta Universitatis Nicolai Copernici', Historia 28, 1993, pp. 137-143; A. Stroynowski, Opozycja sejmowa $w$ dobie rządów Rady Nieustającej. Studium z dziejów kultury politycznej, Łódź 2005, pp. 114-117.

${ }^{14}$ Assessors' duties were performed by the following officials from the land of Liw: dapifer Michał Cieszkowski, pincerna Michał Buyno, notarius terrestris and castrensis Antoni Jaczewski, treasurer Szczepan (Stefan) Zambrzycki, iudex castrensis Franciszek Ksawery Jasieński and Ignacy Gołacki. See Laudum and instruction for envoys, Liw, August 17, 1778, AGAD, ZP 125, sheets 223-224; W. Filipczak, Sejm 1778..., p. 74.

${ }^{15}$ Note de principaux executeurs l'ouvrage a faire au dietines (documents of the sejm in 1776), AGAD, ZP 114, sheet 3; W. Filipczak, Życie sejmikowe..., p. 34.

${ }^{16}$ Stanisław August's universal, Warsaw, May 22, 1780, AGAD, Sieradzkie grodzkie, relacyjne / The books of Sieradz castle [hereinafter: SGR] 160, sheet 951; W. Filipczak, Życie sejmikowe..., p. 57. 
Rudziński, the voivode of Mazovia ${ }^{17}$ ), he was 'persecuted' by some citizens, which was meant to become an issue at the court of land in Liw. K. Krasiński asked the king to support him by sending a suggestion to I. Cieciszowski, the judge at this particular court ${ }^{18}$. The crown castrametator owned considerable property in Mazovia. Also, he was elected an envoy (from the land of Ciechanow and the voivodship of Płock $)^{19}$. K. Krasinski became the deputy for the Crown Tribunal as an alternate from the land of Liw at the sejmik of Mazovia voivodship in July 1777. The crown castrametator was then elected the marshal of Tribunal ${ }^{20}$. K. Krasiński was undoubtedly regarded as a royalist, considering the fact that in 1782 he became the marshal of the Sejm due to the king's support. However, he disappointed the monarch while performing his duties, which is why he was not promoted to the senator's office ${ }^{21}$. The king replied to Krasiński's letter dated May 31 at once (on the same day) informing him that his request was granted ${ }^{22}$. At the same time Stanisław August made a demand through Stanisław Badeni that A. Cieciszowski intervenes in that matter ${ }^{23}$. The head of the monarch's private chancellery immediately wrote to his brother, Ignacy. He emphasised the integrity of K. Krasinski, which could be seen in his role as the marshal of Tribunal. He also mentioned I. Cieciszowski's attachment to the sons of Mazovian voivodes, the Rudziński family (Rudzieński) ${ }^{24}$. At the same time A. Cieciszowski wrote a letter to K. Krasinski, informing him that he had fulfilled the monarch's order, and stressing the fact that he believed in his brother's justice. If the decision that was to be made did not meet

${ }^{17}$ W. Szczygielski, Krasiński Kazimierz, [in:] PSB, vol. XV, Wrocław 1970, pp. $184-186$.

${ }^{18}$ K. Krasiński to king, Proszowice, May 31, 1780, Biblioteka Ksiażąt Czartoryskich w Krakowie / The Princes Czartoryski Library in Cracow [hereinafter: $\mathrm{BCz}]$ 669, pp. 181-182.

${ }^{19}$ W. Szczygielski, Krasiński Kazimierz..., pp. 184-186.

${ }^{20}$ Ordinatio Judiciorum Ordinariorum Generalium Tribunalis... (ordinatio Crown Tribunal in 1777, old print in: $\mathrm{BCz} 803$ ); Deputaci Trybunału Koronnego 15781794. Spis, part 5 (1751-1794), ed. J. Ternes, Warszawa 2017, p. 218, 221; M. Roguski, op. cit., p. 370. Sejmiks of the voivodship in Warsaw elected two deputies representing two particular lands. See J. Choińska-Mika, Sejmiki mazowieckie..., p. 33.

${ }^{21}$ W. Filipczak, Życie sejmikowe..., p. 93.

${ }^{22}$ King to K. Krasiński, May 31, 1780, BCz 669, p. 183.

${ }^{23}$ A. Cieciszowski to king, June 1, 1780, $\mathrm{BCz} 724$, p. 147.

${ }^{24}$ A. Cieciszowski to I. Cieciszowski, Warsaw, May 31, 1780 (the copy of the letter), $\mathrm{BCz} 724$, p. 145. 
the castrametator's expectations, the head of the king's private chancellery offered to intercede so as to arrive at a compromise ${ }^{25}$. Also in his letter to Stanislaw August A. Cieciszowski highlighted his conviction that the decrees of the iudex terrestris of Liw were fair $^{26}$. Several days later K. Krasiński replied to the letter by the crown notary stating that he was fully aware of the 'virtue' of the Cieciszowski brothers. He explained that the reason why he sought the royal protection was that the verdict in the case did not only depend on the iudex terrestris of Liw. It was supposed to follow from the decision of the whole judiciary committee, whose members should know that the Crown castrametator was supported by the $\mathrm{king}^{27}$. I. Cieciszowski answered K. Krasiński's letter (I am not familiar with this reply), and on June 5, 1780 he answered his brother's message. The letter intimates that the iudex terrestris of Liw felt piqued because of the Crown castrametator's attempts to exert pressure on his decision. I. Cieciszowski stated that he answered the message in his capacity as the judge and not as the head of the chancellery's brother. I. Cieciszowski referred to his fellow citizens' testimony in order to stress the fact that while performing his duties for 16 years (as the vice-capitaneus and iudex terrestris) he had always aimed to combine justice with 'delicacy'. He stated that so far nobody had complained about his decisions in front of the Crown Tribunal, or the king and the Permanent Council ${ }^{28}$.

The truthfulness of the above words cannot be verified because neither the books documenting legal issues in Liw nor the tribunal acts have been preserved. Still, it cannot be disputed that during the Piotrków term of the Tribunal in November the following year the royalists effectively defended 'the honour of the land of Liw' in the course of the case concerning the money taken over from the court (iudicium terrestre) of $\mathrm{Liw}^{29}$. The correspondence analysed above reveals particular characteristics of a clerk and nobility activist operating on the level of the land. I. Cieciszowski was easily

${ }^{25}$ A. Cieciszowski to K. Krasiński, Warsaw, May 31, 1780 (the copy of the letter), BCz 724, pp. 143-144.

${ }^{26}$ A. Cieciszowski to king, June 1, 1780, BCz 724, p. 147.

${ }^{27}$ K. Krasiński to A. Cieciszowski, June 2, 1780, BCz 669, p. 185.

${ }^{28}$ I. Cieciszowski to A. Cieciszowski, June 5, 1780, BCz 669, pp. 189-191.

${ }^{29}$ J. Zambrzycki to A. Cieciszowski, [Piotrków], September 14, 1781, BCz 695, p. 225 . 
slighted and acutely aware of his dignity, which he often flaunted in his letters to the much more influential addresses.

The tension and resentment discussed above do not seem to have influenced the course of the sejmik which gathered in Liw on August 21, 1780. The proceedings were opened by the castellan of Liw, Krzysztof Cieszkowski ${ }^{30}$. He had been in charge of the highest office in his land for more than two years. The king decided to offer him that office during the session of the Permanent Council on July 28,1778 . On the same day the members of the council chose three candidates for the office of the castellan of Liw, which remained vacant after Ignacy Cieciszowski resigned ${ }^{31}$. Jan Michałowski, the burgrabius of Liw, was elected the marshal of the sejmik. The newly elected assessors included burgrabius Adam Gałecki and Jakub Roguski, the susceptantes of Liw, Marcin and Lukasz Polkowski, as well as Ignacy Gołaski and Aleksander Gradowski ${ }^{32}$. Jan Michałowski, who was in charge of the sejmik, played the role of the counsellor at the local confederacy in $1767^{33}$. Apparently, his being elected the marshal was preceded by putting an end to resentment caused, among others, by the candidate himself ${ }^{34}$. J. Roguski had earlier been an assessor at the sejmik that chose candidates for the judiciary offices in the land of Liw on August 21, 1777 , and at the economic session held on the very same day ${ }^{35}$. Adam Gałecki and Marcin Polkowski assisted the marshal at the sejmik that chose candidates for the office of notarius terrestris in $1777^{36}$. Golaski performed the assessor's duties at the pre-sejm proceedings in August $1778^{37}$. The role of the royal legate was embraced on August 21, 1780 by the son of the succamerarius of

${ }^{30}$ Laudum of the sejmik, Liw, August 21, 1780, Biblioteka Naukowa PAU i PAN w Krakowie / The Science Library of the PAAS and the PAS in Cracow, manuscript [hereinafter: BPAU] 8322, sheet 582.

${ }^{31}$ Minutes of the Permanent Council, July 28, 1778, AGAD, Metryka Litewska / The Lithuanian Metrica, section VII [hereinafter: ML VII], No. 20, p. 201; M. Roguski, op. cit., p. 379.

${ }^{32}$ Laudum of the sejmik, Liw, August 21, 1780, BPAU 8322, pp. 582-582v; L. Zalewski, Szlachta ziemi..., p. 53.

${ }^{33}$ M. Roguski, op. cit., p. 381.

34 [I. Cieciszowski to A. Cieciszowski], Puncta to the instruction and a report from the sejmik [Liw, August 21, 1780], BCz 673, pp. 495-496.

${ }^{35}$ Lauda of the sejmiks, Liw, August 21, 1777, BPAU 8322, sheets 576v-577 and $579 \mathrm{v}$.

${ }^{36}$ Laudum of the sejmik, Liw, November 6, 1777, BPAU 8322, sheets 580v-581.

${ }^{37}$ Laudum and instruction for envoys, Liw, August 17, 1778, AGAD, ZP 125, sheets 223v, 225. 
Liw, Józef Grzybowski, whose father, Stanisław, had been elected the candidate for the office of succamerarius in August 1777 (S. Grzybowski was the envoy from Liw at the sejm in 1776 when he was the dapifer of Liw) ${ }^{38}$. The envoys representing Liw at the Sejm which was to start on October 2, 1780 were unanimously elected. Parliamentary mandates were obtained by the venator of Liw, Szczepan (Stefan) Zambrzycki, and the capitaneus of Kleszczele, Florian Cieszkowski ${ }^{39}$. As the treasurer of Liw, S. Zambrzycki also acted as the marshal of the pre-sejm sejmik in July $1776^{40}$. Cieszkowski's parents, castellan I. Cieszkowski and Franciszka Suffczyńska, entitled him to the role of capitaneus of Kleszczele in the voivodship of Podlachia ${ }^{41}$ (the agreement to hand it down to him was prepared in 1774). The representatives of the land of Liw in Parliament obtained an instruction for envoys including 18 elements $^{42}$. A. Cieciszowski only received 15 of them (he obtained them from his brother). This may indicate that the final version of suggestions for the envoys was drawn up after the session (which had ended about $12 \mathrm{pm})^{43}$.

Since many of their elements recur throughout, I am going to revert to the instructions for the envoys of Liw later in this article. At this stage I would like to focus on a particular issue concerning the current political problems. The issue in question was tackled in the Zbiór Praw Sadowych [Collection of Court Laws] titled Zamoyski's Code drawn up by the team supervised by Andrzej Zamoyski and

${ }^{38}$ Lauda of the sejmiks, Liw, August 21, 1777 and August 21, 1780, BPAU 8322, sheets 576v, 582v. Instruction for envoys, Liw, July 15, 1776, AGAD, ZP 125, p. 89; M. Roguski, op. cit., p. 383 (ref. No. 32).

${ }^{39}$ Laudum of the sejmik, Liw, August 21, 1780, BPAU 8322, p. 582v; [I. Cieciszowski to A. Cieciszowski], Puncta to the instruction and a report from the sejmik [Liw, August 21, 1780], BCz 673, p. 496.

${ }^{40}$ Instruction for envoys, Liw, July 15, 1776, AGAD, ZP 125, sheet 91; L. Zalewski, Szlachta ziemi..., p. 52 .

${ }^{41}$ K. Chłapowski, Starostowie niegrodowi $w$ Koronie 1565-1795 (Materiały źródłowe), Warszawa-Bellerice-sur-Allier 2017, p. 306. See M. Roguski, op. cit., p. 379.

${ }^{42}$ Instruction for envoys, Liw, August 21, 1780, BPAU 8322, sheets 584-587.

${ }^{43}$ [I. Cieciszowski to A. Cieciszowski], Puncta to the instruction and a report from the sejmik [Liw, August 21, 1780], $\mathrm{BCz}$ 673, pp. 495-496. The first point and some others were missing. The first one contained, among others, a conventional announcement of loyalty to the king. The others referred to a) approving the foundation of communitarian priests (Apostolic Union of Secular Priests); b) the fees to maintain the bridge on the river Liwiec. See BPAU 8322, sheets 584-587. 
printed in $1778^{44}$. The noblemen from the land of Liw demanded that the former chancellor's proposals 'should by no means be accepted' since they clashed with the customs of the country and freedom of the nation ${ }^{45}$. This does not prove that the sejmik of Liw was influenced by the king's opponents. Though dominated by the royalists, the Mazovian sejmiks could be very critical of the Zbior Praw Sadowych ${ }^{46}$.

In the course of the sejmik discussed above envoys were also elected to represent the land of Liw in front of the king. They were Ludwik Cieciszowski, the son of dapifer of Liw, and Ludwik Dłużewski, the son of vexillifer of Chelm. In accordance with a separate instruction they were to thank Stanisław August for his concern for the public welfare, pay their respects to his majesty and recommend the envoys from the land of Liw to the king's attention ${ }^{47}$.

In accordance with the bill from 1778, the envoys representing the land of Liw at the former Sejm were supposed to submit a report at the pre-sejm sejmik in 1780 because it was the first sejmik after the Sejm ended (in the voivodship of Mazovia this usually involved the next sejmik that elected the envoys) ${ }^{48}$. However, none of the envoys from Liw in 1778 arrived at the successive pre-sejm sejmik. J. Ogrodzki was dead, and A. Cieciszowski sent a written report. The new head of the king's private chancellery justified his absence by referring to a number of duties (though two years before the same reason was not a hindrance for either of the heads, who arrived at the sejmik in order to gain the envoys' status). The court was opposed to the attempt to restore the sejmiks whose purpose was to inform about the proceedings of the previous Sejm. Still, the expectations of nobility had to be taken into account. The sejmik of Liw demanded that these particular sejmiks should be restored as

${ }^{44}$ A. Borkowska-Bagieńska, Zbiór praw sądowych Andrzeja Zamoyskiego, Poznań 1986, pp. 17-50, 305-316.

${ }^{45}$ Instruction for envoys, Liw, August 21, 1780, BPAU 8322, sheet 585v.

${ }^{46}$ W. Filipczak, Sejmiki ziemi czerskiej 1780-1786, 'Przegląd Nauk Historycznych' 2010, vol. IX, No. 1, pp. 144-145; idem, Sejmiki ziemi nurskiej 1780-1786, 'Przegląd Nauk Historycznych' 2014, vol. XIII, No. 1, p. 32; idem, Sejmiki ziemi zakroczymskiej 1778-1786, 'Przegląd Nauk Historycznych' 2015, vol. XIV, No. 2, p. 96.

${ }^{47}$ Instruction for envoys to the king, Liw, August 21, 1780, AGAD, ZP 125, sheets 304-305 (see also: BPAU 8322, sheets 588-588v).

${ }^{48}$ Vol. leg., vol. VIII, Petersburg 1860, p. 580. Sejmiki relationis dla Korony i Xięstwa Litewskiego; W. Filipczak, Sejm 1778..., p. 308, pp. 337-338. 
is evident from the instruction for envoys from $1776^{49}$. Even before the envoys were elected, iudex terrestris I. Cieciszowski stood up to broach the matter, and asked the gathering to agree to the public reading of his brother's report, which was 'willingly' granted ${ }^{50}$. This was expressed in the sejmik resolution where the report by the Crown notary was described as 'sufficient'. The laudum also has it that A. Cieciszowski complied with the demands of the law on that matter. The laudum expressed gratitude to the former envoy and 'the beloved son of his land', because he did not disappoint the noblemen while performing his duties. The marshal of the sejmik was prevailed upon to reply to the Crown notary ${ }^{51}$. As early as on the day when the sejmik was held, J. Michałowski sent a letter to A. Cieciszowski stating that 'his land knew the numerous occupations' of the addressee and that his written report met with contentment ${ }^{52}$. A day later two more letters were dispatched to the Crown notary; the first one was by castellan K. Cieszkowski, the latter - by S. Grzybowski; both senders emphasised that the sejmik had graciously responded to the written report ${ }^{53}$. Venator S. Zambrzycki confirmed that opinion saying that the citizens had been convinced of the Crown notary's 'occupations'

During the same session of the sejmik (August 21, 1780) the noblemen of Liw addressed the issues that were typical for economic gathering. The text of the laudum suggests that the gathering was not treated as a separate sejmik but as a sequel to the pre-sejm proceedings $^{55}$. In accordance with the coronation bill from 1764, the economic sejmiks of the Mazovian principality were to be held a day after the ones that elected envoys, which was different from the usual course in the remaining Crown territories (where these sejmiks gathered a day after the sejmiks that elected deputies) ${ }^{56}$. However, in some voivodships and lands the proceedings were

${ }^{49}$ Instruction for envoys, Liw, July 15, 1776, AGAD, ZP 125, sheet 89; W. Filipczak, Sejm 1778..., p. 139.

50 [I. Cieciszowski] to A. Cieciszowski [Liw, August 21, 1780], BCz 673, p. 495; S. Zambrzycki to A. Cieciszowski, August 23, 1780, BCz 695, p. 155.

${ }^{51}$ Laudum of the sejmik, Liw, August 21, 1780, BPAU 8322, sheets 582v-583.

52 J. Michałowski to A. Cieciszowski, Liw, August 21, 1780, BCz 673, p. 493.

${ }^{53}$ K. Cieszkowski to A. Cieciszowski, August 22, $1780, \mathrm{BCz} 655$, p. 1323; S. Grzybowski to A. Cieciszowski, August 22, 1780, BCz 663, p. 563.

${ }^{54} \mathrm{~S}$. Zambrzycki to A. Cieciszowski, August 23, 1780, BCz 695, p. 155.

${ }^{55}$ Laudum of the sejmik, Liw, August 21, 1780, BPAU 8322, sheets 583-583v.

${ }^{56}$ Vol. leg., vol. VII, p. 156. Ustanowienie sejmików gospodarskich w województwie mazowieckim; W. Filipczak, Sejmiki ziemi czerskiej..., p. 146. 
sometimes held on the day of the sejmik, thus preceding the date specified in the bill (probably to save time) ${ }^{57}$. Still, the Mazovian principality often stuck to the local regulation, and the sejmiks were held at the time required by the law ${ }^{58}$. On August 21, 1780 it was decided in the land of Liw that the local castle, which was beyond repair, should be taken apart and the building material should be used for the chancellery and archives ${ }^{59}$. Notarius terrestris and castrensis from the land of Liw was granted discharge for the money that was to be used for the inducta and binding of the books documenting legal issues. The next matter discussed was the settlement of financial means gained due to the sale of 30 barrels of salt (1912 zlotys). The above sum was handed over to succamerarius S. Grzybowski to be returned with interest. The yearly interest was to be used to cover the cost of repairing the church benches ${ }^{60}$ (possibly at the place where the gathering was held). The fact of granting discharge for the money earned by selling the salt was discussed at the economic sejmik in Liw on August 21, 1777. The economic sejmik was held (in defiance of the law) after the end of the sejmik where candidates for succamerarius were elected. In contrast to the procedure in 1780, two separate lauda had documented the two respective events ${ }^{61}$.

The next sejmik that elected candidates for envoys was summoned on the basis of Stanisław August's universal dated May 22, 1782. The sejmik in question gathered on August 19, $1782^{62}$. The pre-sejm

57 J. Włodarczyk, Sejmiki łęczyckie, Łódź 1973, p. 94; A. Lityński, Sejmiki województwa płockiego przed $i w$ czasie Sejmu Czteroletniego. $Z$ badań nad organizacja i funkcjonowaniem, [in:] W dwusetna rocznice wolnego Sejmu. Ludzie - państwo - prawo czasów Sejmu Czteroletniego, ed. A. Lityński, Katowice 1988, p. 80; W. Filipczak, Życie sejmikowe..., p. 608.

${ }^{58}$ W. Filipczak, Sejmiki ziemi czerskiej..., p. 177; idem, Sejmiki ziemi zakroczymskiej..., p. 108.

${ }^{59}$ Laudum of the sejmik, Liw, August 21, 1780, BPAU 8322, sheet 583; L. Zalewski, Szlachta ziemi..., p. 53. In the instruction for envoys (Liw, August 21,1780 ) it was proposed that the Sejm should approve this decision: BPAU 8322, sheet $586 \mathrm{v}$.

${ }^{60}$ Laudum of the sejmik, Liw, August 21, 1780, BPAU 8322, sheets 583-583v.

${ }^{61}$ Laudum of the economic sejmik, Liw, August 21, 1777, BPAU 8322, sheets $578-579 v$. The sejmik put an end to the pretensions that the landowners were carrying on with regarding the vexillifer of Liw, Ignacy Zielinski, who was charged with using the acquired money without informing anyone.

${ }^{62}$ Stanisław August's universal, Warsaw, May 22, 1782, AGAD, Zakroczymskie grodzkie, relacje / The books of Zakroczym castle [hereinafter: ZGR] 79, sheet 728; W. Filipczak, Życie sejmikowe..., p. 86. 
campaign was launched in a tenuous political situation caused by the magnates' opposition to the court because of the incapacitation of the mentally ill bishop of Cracow, Kajetan Soltyk (military assistance was summoned then $)^{63}$. While corresponding with the prominent royalist activists in the country, the king emphasised the need to hush up the Cracow affair in the instructions for envoys $^{64}$. The lists of potential envoys drawn up in the king's private chancellery mentioned some candidates from the land of Liw: iudex terrestris I. Cieciszowski (supported by the court), as well as S. Grzybowski, the succamerarius of Liw; one candidate came from the Ossoliński family (the first person considered was the capitaneus of Drohiczyn, Jan Onufry, then it was the capitaneus of Sandomierz's elder son). Besides, the voivode of Mazovia's son, Rudziński (Rudzieński), was initially mentioned on the list. Since the name of the last candidate was crossed out in the plan of the sejmik action (planta), it must have transpired earlier that he would not apply for being elected in the land of Liw ${ }^{65}$. Thus the choice may have referred to Kazimierz Rudziński, the voivode of Mazovia's younger son, who successfully applied for the envoy's mandate in the neighbouring land of Czersk ${ }^{66}$. In a letter dated August 13, 1782 Antoni Rudziński, the voivode of Mazovia's son, who was then trying to obtain the function of an envoy from Liw, wrote to A. Cieciszowski about an agreement concluded in Warsaw in the presence of chancellor Antoni O. Okęcki. In light of this agreement the envoys' mandates were supposed to go to two representatives of the Ossolinski family, but no mention of the sejmik in Liw was made (the function of an envoy from Liw was promised to one of these candidates). The letter suggests that the idea of electing one of the Ossolinski brothers to represent Liw resurfaced in the discussions ${ }^{67}$.

The atmosphere of preparations for the sejmiks in the land of Liw may have been affected by contentious legal issues. Klemens Jasieński, the vice-capitaneus of Liw, tried to regain the money lent to a bankrupt, namely, the capitaneus of Liw, Tadeusz Grabianka

${ }^{63}$ K. Rudnicki, Biskup Kajetan Sołtyk 1715-1788, Kraków-Warszawa 1906, pp. 207-242; M. Czeppe, Sołtyk Kajetan Ignacy, [in:] PSB, vol. XL, WarszawaKraków 2001, pp. 400-402.

${ }^{64}$ W. Filipczak, Życie sejmikowe..., pp. 86-87.

${ }^{65}$ Candidates to the Sejm of 1782, AGAD, ZP 126, sheet $118 \mathrm{v}$.

${ }^{66}$ W. Filipczak, Sejmiki ziemi czerskiej..., pp. 151-154.

${ }^{67}$ A. Rudzieński to A. Cieciszowski, Lublin, August 13, 1782, BCz 686, p. 768. 
(who did not take part in the political life ${ }^{68}$ ). Jasieński sought to satisfy his claims from the income of the starosty of Liw. Grabianka promised to sell the rights to his estate to capitaneus of Sulejów's son, (Stanisław?) Ossoliński. K. Jasieński asked the king for particular mediators, that is, A. Jaczewski (currently in charge of the estate) and the castellan of Warsaw, Maciej Sobolewski ${ }^{69}$.

The pre-sejm sejmik in Liw was opened by castellan K. Cieszkowski on August 19, 1782. Józef Grzybowski, the succamerarius of Liw's son, who had been a royal envoy at the sejmik two years earlier, was elected the marshal. Three burgrubius from Liw were supposed to assist him as assessors: Jan Michałowski (the marshal of the sejmik in 1780), Jan Bełdowski and Franciszek Radzikowski as well as susceptans terrestris and castrensis Łukasz Polkowski (an assessor two years earlier), dapifer of Liw's son, Balcer (Baltazar) Cieszkowski, and Michał Mroczek ${ }^{70}$. M. Mroczek had assisted the marshal in the gathering connected with election in November $1777^{71}$. Jacek Cieciszowski, the son of Ignacy, the iudex terrestris of Liw, appeared in the role of the royal legate at the sejmik in $1782^{72}$. Judge I. Cieciszowski and Stanisław Ossolinski, the son of capitaneus of Sulejów, were elected envoys to the Sejm unanimously and without objection. F. Cieszkowski, the capitaneus of Kleszczele, read a report from the previous Sejm speaking for himself and on behalf of venator S. Zambrzycki. The report was accepted with gratitude by the gathering. The resolution stressed the fact that the envoys at the Sejm had not broken trust ${ }^{73}$ (phrases used in the laudum two years before were repeated).

The newly elected envoys were provided with an instruction composed of 19 items. Politically, the second item on the list was the most controversial thing. It made a demand that the cardinal law 'neminem captivabimus nisi jure victum' should be strictly obeyed ${ }^{74}$. The court interpreted it as an allusion to the incapacitation of bishop K. Soltyk, which was probably the case ${ }^{75}$. The fact that such

${ }^{68}$ M. Roguski, op. cit., p. 370.

${ }^{69} \mathrm{~K}$. Jasieński to king, undated and July 27, 1782, BCz 666, p. 281, 283.

${ }^{70}$ Laudum of the sejmik, Liw, August 19, 1782, BPAU 8322, pp. 589-589v; L. Zalewski, Szlachta ziemi..., p. 53.

${ }^{71}$ Laudum of the sejmik, Liw, November 6, 1777, BPAU 8322, sheets 580v-581.

${ }^{72}$ Laudum of the sejmik, Liw, August 19, 1782, BPAU 8322, sheet 589v.

${ }^{73}$ Laudum of the sejmik, Liw, August 19, 1782, BPAU 8322, sheets 589v-590.

${ }^{74}$ Instruction for envoys, Liw, August 19, 1782, BCz 8322, sheets 591-591v.

${ }^{75}$ Excerpt of the instruction for envoys of the land of Liw and note, undated (acts of the sejm in 1782), AGAD, ZP 126, sheets 155, 218. 
a statement appeared in the resolution of the sejmik known for its royalist sympathies must be regarded as a considerable surprise. The other item that flew in the face of the court's expectations but was supported by nobility (including the noblemen connected with the royalist party) postulated that the term of a counsellor in the Permanent Council and that of a commissar (possibly a treasure commissar) should not exceed four years, which was meant to provide access to these functions to a bigger number of people ${ }^{76}$. The lack of clarity in the statement makes it impossible to decide whether it concerned the term of both functions in combination. The second item of the instruction which alluded to the Cracow 'affair' does not mean that the sejmik was under the sway of the king's opponents. The proof of this can be found in the results of the Sejm poll concerning the project submitted by Stanisław K. Potocki titled $O$ rezolucjach Rady [About the Council's Resolutions], which was endorsed by the malcontents (it concerned the decisions made by the Permanent Council on the subject of K. Soltyk) ${ }^{77}$. In all the open votes on particular items in the project (there were 8) castellan K. Cieszkowski and both envoys from Liw supported the court's stand on the matter, and their attendance at the time of voting was $100 \%{ }^{78}$.

The economic gathering took place in Liw on the same day as the sejmik that elected the envoys (August 19, 1782). In contrast to 1780 , separate resolutions were written down. The candidates elected in the pre-sejm gathering acted as the marshal and assessors for the whole time ${ }^{79}$. The adopted resolutions concerned the use of funds gained due to the sale of 30 barrels of salt. Obtained in

${ }^{76}$ Instruction for envoys, Liw, August 19, 1782, BPAU 8322, sheet 591v; W. Filipczak, Szlachta koronna wobec reformy sejmu $w$ świetle instrukcji poselskich z lat 1778-1786, [in:] Między Barokiem a Oświeceniem. Parlamentaryzm, eds B. Krysztopa-Czupryńska, J. Kiełbik, Olsztyn 2016, p. 66. See L. Zalewski, Szlachta ziemi..., p. 53.

${ }^{77}$ S.K. Potocki, O rezolucjach Rady, AGAD, ZP 126, sheet 384; Dyaryusz Seymu wolnego ordynaryinego... 1782..., ed. P. Kiciński, Warszawa 1782, pp. 264267; A. Stroynowski, Opozycja sejmowa..., pp. 163-164; W. Filipczak, Życie sejmikowe..., p. 96.

${ }^{78}$ Tables of open votes in the envoys' chamber, AGAD, ZP 108, p. 31v, 35v, $48 \mathrm{v}, 52 \mathrm{v}, 66 \mathrm{v}, 70 \mathrm{v}, 83 \mathrm{v}, 87 \mathrm{v}$; Tables of open votes in the senate, AGAD, Archiwum Publiczne Potockich / Public Archives of the Potocki Family, No. 313, vol. XI, sheets 321, 326, 334, 339, 347, 352, 359, 364.

${ }^{79}$ Laudum of the economic sejmik, Liw, August 19, 1782, BPAU 8322, sheets 595-596v. 
this way, the sum of 1912 zlotys was given to A. Jaczewski, the notarius of Liw. The man in question was elected the Mazovian deputy at the sejmik of Mazovian voivodship in Warsaw in July 1782 (an alternate was to be chosen by the land of Zakroczym and the land of Ciechanow ${ }^{80}$. J. Michałowski, the burgrabius of Liw, who covered the cost of regaining the above-mentioned sum was rewarded with the amount of 100 zlotys, generated by interest on capital. The remaining money gained in this way was donated to the restoration of benches at the church in Liw. The sum of 1912 zlotys which had sat in escrow was thus paid by its custodian, S. Grzybowski, who was granted discharge by the sejmik upon complying with the resolution ${ }^{81}$. The above decisions resulting from the economic gathering were a sequel to the activities from August 1780 , and completed the process of allocating financial resources gained by the sejmik due to the salt that the noblemen of Liw were entitled to. The issue was essential because the reforms from 1766-1768 deprived the sejmiks of the usual sources of income from taxes (czopowe and szelężne) ${ }^{82}$.

The political atmosphere of the sejmik campaign before the Sejm of Grodno from 1784 was much calmer than two years before. Stanisław August's universal dated May 20, 1784 stated that the sejmiks would be held on August $16^{83}$. Composed in the king's private chancellery, the list of candidates who ran for the functions of envoys from Liw included three names. A strong candidate to get the mandate was iudex terrestris I. Cieciszowski, whose position did not weaken after the death of his brother, Adam, in $1783^{84}$. When it comes to the promotion to envoyship, the candidates

${ }^{80}$ Laudum of the economic sejmik, Liw, August 19, 1782, BPAU 8322, sheet 595v; Deputaci Trybunatu..., part 5, p. 250. During the term 1777-1778 Jaczewski (an alternate from the lands of Liw and Nur) was given the role - by the sejmik - of the notary in charge of decrees from the regestr of Mazovian voivodship. See ibidem, part 5, p. 221.

${ }^{81}$ Laudum of the economic sejmik, Liw, August 19, 1782, BPAU 8322, pp. 595v596.

${ }^{82}$ A.B. Zakrzewski, Sejmiki Wielkiego Księstwa Litewskiego XVI-XVIII w. Ustrój ifunkcjonowanie: sejmik trocki, Warszawa 2000, pp. 210-211; M. Zwierzykowski, Komisja Skarbowa Poznańska. $Z$ dziejów sejmikowej administracji $i$ sadownictwa skarbowego $w$ Wielkopolsce $w$ XVII i XVIII wieku, Poznań 2003, pp. 247-253.

${ }^{83}$ Stanisław August's universal, Warsaw, May 20, 1784, AGAD, SGR 168, sheets 543v-544; W. Filipczak, Życie sejmikowe..., p. 119.

${ }^{84}$ Candidates to the Sejm of 1784 , AGAD, ZP 128, sheet 29; M. Rymszyna, op. cit., p. 115. 
taken into consideration were: notarius A. Jaczewski and the pincerna of Liw, Onufry Oborski ${ }^{85}$. Four years later O. Oborski, who was then a subdapifer, was elected a candidate for the office of succamerarius of the land of Liw (he eventually gained the office of iudex terrestris) ${ }^{86}$. The pre-sejm sejmik held in the parish church in Liw on August 16, 1784 was preceded by a mass ('having first prayed to God...'). The session was again opened by K. Cieszkowski. Łukasz Polkowski was elected the marshal of the sejmik (he had performed assessor's duties during two previous pre-sejm sejmiks). The burgrabius of Liw, G. Strupiechowski, Antoni Zaliwski, A. Gradowski and Aleksander Rozwadowski became assessors ${ }^{87}$. Gradowski had already assisted the marshal of the sejmik at the assembly electing envoys and at the economic gathering on August $21,1780^{88}$. Kazimierz Dłużewski became the royal legate for the sejmik of Liw in $1784^{89}$. Iudex terrestris I. Cieciszowski and notarius terrestris and castrensis A. Jaczewski were unanimously elected the envoys to the Sejm of Grodno without the slightest difference of opinion ${ }^{\prime 90}$. The resolution does not mention the fact whether any other candidates were considered. The laudum, however, contains a formula that describes the accepted resolution as unanimous and concordant ${ }^{91}$.

The envoys from the land of Liw to the Sejm of Grodno were provided with an instruction composed of 13 (unnumbered) items ${ }^{92}$. The instruction contained a eulogy of the king's policy in distributing nominations. The relevant passage concerned the promotion of Michał Mniszech and Kazimierz Raczyński to the offices of Crown marshals, and the transfer of the voivodship of Mazovia to Antoni Małachowski - all the above-mentioned politicians belonged to

${ }^{85}$ Candidates to the Sejm of 1784, AGAD, ZP 128, sheet 29; W. Szczygielski, Oborski Onufry, [in:] PSB, vol. XXIII, 1978, pp. 450-451. Onufry Oborski was elected an envoy of Liw to the Sejm during the election of the king in 1764.

${ }^{86}$ Laudum of the sejmik, Liw, August 16, 1788, BPAU 8322, sheet 604v; M. Roguski, op. cit., p. 378.

${ }^{87}$ Laudum and instruction for envoys, Liw, August 16, 1784, BPAU 8322, sheet 597; L. Zalewski, Szlachta ziemi..., p. 54.

${ }^{88}$ Laudum and instruction for envoys, Liw, August 21, 1780, BCz 8322, sheets $583 \mathrm{v}, 587$.

${ }^{89}$ Laudum of the sejmik, Liw, August 16, 1784, BPAU 8322, sheet 597; M. Roguski, op. cit., p. 383 (ref. No. 32).

${ }^{90}$ Laudum of the sejmik, Liw, August 16, 1784, BPAU 8322, sheet 597.

${ }^{91}$ Laudum of the sejmik, Liw, August 16, 1784, BPAU 8322, sheet 597v.

${ }^{92}$ Instruction for envoys, Liw, August 16, 1784, BPAU 8322, sheets 598-599. 
the milieu of the most influential activists in the royalist party ${ }^{93}$. However, the instruction did not mention the fact that Ignacy Potocki, one of the leaders of the magnates' opposition, had been nominated for the office of Court Marshal of Lithuania; such things happened at some sejmiks on the territory of the Crown (even when the gathering was dominated by the royalists) ${ }^{94}$. The instruction was rather critical of the Permanent Council. The noblemen demanded that the resolutions that overstepped its competences by trespassing on the territory of the judiciary power should be called into question during the Sejm and waived ${ }^{95}$. Suggestions of this kind could be drawn up even at the sejmiks controlled by the supporters of the court ${ }^{96}$. The content of the instruction does not offer unequivocal clues as to the political views of the sejmik. Still, the political activity of the parliamentary members from Liw testifies to the royalists' conspicuous success. Iudex terrestris I. Cieciszowski played the role of the secretary in the deputation 'examining' the Permanent Council; the deputation was indeed crucial for the court. Because of his role, I. Cieciszowski read out the minutes resulting from the control of the Permanent Council at the gathering of both chambers (on October 20) ${ }^{97}$. The fact that he was asked to perform this task proves that the brother of the recently deceased head of the king's private chancellery had gained considerable trust.

There is no information in the preserved sources whether an economic gathering took place after the sejmik that chose envoys.

The next pre-sejm sejmik was summoned as a result of the king's universal (dated May 25) on August 21, $1786^{98}$. Despite A. Danilczyk's research on the Sejm of 1786, little is known about the course of preparations for the sejmik in the land of $\mathrm{Liw}^{99}$. The

${ }^{93}$ Instruction for envoys, Liw, August 16, 1784, BPAU 8322, sheet 598. See J. Michalski, Sejmiki poselskie 1788 roku, part 2, 'Przegląd Historyczny' 1960, vol. LI, issue 1-2, p. 53, pp. 341-342, p. 348, 350; J. Dygdała, Raczyński Kazimierz, [in:] PSB, vol. XXIX, Wrocław 1986, pp. 646-648.

${ }^{94}$ W. Filipczak, Życie sejmikowe..., p. 540.

${ }^{95}$ Instruction for envoys, Liw, August 16, 1784, BPAU 8322, sheet 598v.

${ }^{96}$ W. Filipczak, Szlachta koronna..., pp. 66-67.

${ }^{97}$ Journal de la diète ordinaire, libre, convoquée à Grodno en 1784, AGAD, ZP 128, sheet 373v, 375v; Dyaryusz Seymu wolnego ordynaryinego... 1784..., ed. M. Tukalski-Nielubowicz, Warszawa 1785, pp. 86-126.

${ }^{98}$ Stanisław August's universal, Warsaw, May 25, 1786, AGAD, ZGR 81, sheet 85; W. Filipczak, Życie sejmikowe..., p. 162.

${ }^{99}$ See A. Danilczyk, op. cit., pp. 88-89. 
list of candidates for the envoys' functions created in Stanisław August's private chancellery mentioned the voivode of Mazovia's younger son, K. Rudziński (the latter's older brother Antoni may have been there as well), iudex terrestris I. Cieciszowski and the pincerna of Liw, S. Zambrzycki, who was also iudex castrensis in Warsaw $^{100}$.

The debate at the sejmik in Liw on August 21, 1786 was opened by the succamerarius of Liw, Stanisław Grzybowski ${ }^{101}$. He had been elected for that office in August 1777 (he was then the dapifer of Liw) ${ }^{102}$. Adam Oborski (possibly the son of dapifer Onufry) showed up as the royal legate and submitted his credentials to the gathering. Grzegorz Strupiechowski, the burgrabius castrensis of Liw, was elected the marshal of the sejmik ${ }^{103}$. He had been an assessor at the previous pre-sejm sejmik of his land ${ }^{104}$. Six men appeared in the role of the marshal's assistants; they were Jacek Cieciszowski, the son of iudex of Liw, who had been the royal legate four years earlier, Ignacy Golawski (the vice-palatinus of Liw), Jan Jaczewski (notarius' son), Antoni Rozwadowski, Tomasz Roguski and Ignacy Dabrowski ${ }^{105}$. J. Cieciszowski and J. Jaczewski were the sons of the envoys of Liw to the former Sejm. Their fathers (I. Cieciszowski and A. Jaczewski) had taken part in the sejmik and submitted a report from the debates in Grodno. Complying with the established tradition in a decorous way, the sejmik expressed gratitude to its representatives for their praiseworthy and 'generally acclaimed performance' at the Sejm ${ }^{106}$. Iudex I. Cieciszowski, and the dapifer and iudex castrensis of Warsaw, S. Zambrzycki (who had earlier received a mandate in 1780 ), became the envoys to the next Sejm ${ }^{107}$.

${ }^{100}$ Candidates to the Sejm [1786], AGAD, ZP 132, sheet 57v; M. Roguski, op. cit., pp. 368-369.

${ }^{101}$ Laudum and instruction for envoys, Liw, August 21, 1786, BPAU 8322, sheet 600 .

${ }^{102}$ Laudum of the sejmik, Liw, August 21, 1777, BPAU 8322, sheet 576v.

${ }^{103}$ Laudum of the sejmik, Liw, August 21, 1786, BPAU 8322, sheet 600; M. Roguski, op. cit., pp. 382-383.

${ }^{104}$ Laudum of the sejmik, Liw, August 16, 1784, BPAU 8322, sheet 597; L. Zalewski, Szlachta ziemi..., p. 54.

${ }^{105}$ Laudum and instruction for envoys, Liw, August 21, 1786, BPAU 8322, sheets 600, 601v; L. Zalewski, Szlachta ziemi..., p. 54.

${ }^{106}$ Laudum and instruction for envoys, Liw, August 21, 1786, BPAU 8322, sheet 600 .

${ }^{107}$ Laudum and instruction for envoys, Liw, August 21, 1786, BPAU 8322, sheet 600v; A. Danilczyk, op. cit., p. 191. 
The instruction for envoys from 1786 contained 17 items and made more allusions to the political situation than in the past. It was postulated that the Committee of the Crown Treasury should not try any cases apart from the ones that pertained to the treasury and were described in legal regulations. The committee was supposed to resign even from 'forum inscriptum ${ }^{108}$ (this referred to the situations when both parties in the transaction agreed to submit to the jurisdiction of the Committee of Crown Treasury). This particular item of the instruction echoes the critique of the Committee of Crown Treasury during the Sejm of Grodno. This was when the Committee was accused of exceeding its competence and delivering verdicts in the cases reserved for other courts. The charge was pressed, among others, by some deputies belonging to the controlling body which was dominated by the royalists ${ }^{109}$. A postulate was added (it echoed an instruction from 1782) that the counsellors and commissars of the Committee should not be elected for other functions connected with executive power for the period of four years after their term in the committee was over ${ }^{110}$. Citizens from the land of Liw also responded to the suggestion of the Military Department dated July 9, 1785, which submitted a particular project to the sejmiks that chose the deputies. The project urged the gathering to recruit the soldiers (for the period of ten years) from a particular region in the way that was in proportion to 'the number of chimneys' in the estates belonging to the king or the clergy, as well as in the private cities and small towns. Particular regiments were supposed to obtain their own recruiting districts ${ }^{111}$. The project was supported in the instruction from Liw. However, the issue of recruiting the candidates for the army from landed estates was evaded, and transferred to the city authorities. The nobility of the land of Liw added an item that

${ }^{108}$ Laudum and instruction for envoys, Liw, August 21, 1786, BPAU 8322, sheet 600v.

${ }^{109}$ G. Bałtruszajtys, Sadownictwo Komisji Skarbowych $w$ sprawach handlowych i przemysłowych (1764-1794), Warszawa 1977, pp. 131-132. More on the subject, see W. Filipczak, Sejmowa kontrola Komisji Skarbu Koronnego $w 1784$ roku [under preparation].

${ }^{110}$ Laudum and instruction for envoys, Liw, August 21, 1786, BPAU 8322, sheet 600v; A. Danilczyk, op. cit., p. 122; W. Filipczak, Szlachta koronna.., p. 66.

${ }^{111}$ E. Rostworowski, Sprawa aukcji wojska na tle sytuacji politycznej przed Sejmem Czteroletnim, Warszawa 1957, pp. 149-150; L. Ratajczyk, Przezwyciężenie kryzysu militarnego Polski przed reformami Sejmu Czteroletniego, Warszawa 1975, pp. 87-88; W. Filipczak, Sejmiki województwa płockiego 1780-1786, 'Przegląd Nauk Historycznych' 2009, vol. VIII, No. 2, p. 44. 
mentioned the creation of the regiment of light cavalry (about 600 horses), which was to minimise the growing number of hooligans, beggars, and pilgrims ${ }^{112}$. There was a political message in an item of the instruction which stated: 'particular people's interests should not absorb the Sejm"113. I think it was an allusion to the possibility of the magnate opponents' inciting an argument concerning the verdict of the marshal's court which sentenced Adam Kazimierz Czartoryski in the Dogrumowa affair, or to the manifesto of Franciszek Ksawery Branicki (the hetman demanded that his name should be removed from the decree ${ }^{114}$. A. Danilczyk discussed the relevant passage, but he did not mention its political context ${ }^{115}$.

It is not known whether an economic gathering was held after the pre-sejm sejmik in the land of Liw in August 1786.

I would like to briefly discuss the most striking suggestions recurring in the instructions for envoys in the years 1780-1786, and unrelated to the political situation ${ }^{116}$. As far as social issues were concerned, the nobles were opposed to indygenats (naturalisations) and nobilitations (1780), though an exception was made for Count de Nassau in $1784^{117}$. A frequent demand voiced during the sejmiks on the territory of the Crown was that the cases of fugitive subjects should be tried at the court that operated in the land from which a given peasant fled $(1782,1784)^{118}$, in a particular gród (judiciary centre) where certificates issued to the 'serfs' could be registered (oblata). Those who employed the people who were not in possession of such certificates were to pay a very high fine $(1784)^{119}$.

${ }^{112}$ Laudum and instruction for envoys, Liw, August 21, 1786, BPAU 8322, sheet 601; A. Danilczyk, op. cit., p. 124.

${ }^{113}$ Laudum and instruction for envoys, Liw, August 21, 1786, BPAU 8322, sheet 601 .

${ }^{114}$ A. Danilczyk, Afera Dogrumoweja konsolidacja opozycji w latach 1785-1786, 'Kwartalnik Historyczny' 2004, vol. CXI, No. 4, pp. 51-73. See A. Stroynowski, Zmiany sytuacji politycznej $w$ Rzeczypospolitej przed ostatnim 'wolnym' sejmem w 1786 r., 'Acta Universitatis Lodziensis', Folia Historica 58, 1996, pp. 91-92.

${ }^{115}$ A. Danilczyk, W kregu afery..., p. 121.

${ }^{116}$ Instructions for envoys from the sejmiks in Liw: August 21, 1780 (BPAU 8322, sheets 584-587), August 19, 1782 (BPAU 8322, sheets 591-594), August 16, 1784 (BPAU 8322, sheets 598-599) and August 21, 1784 (BPAU 8322, sheets $600 \mathrm{v}-601 \mathrm{v})$ are the source on which the postulates are based.

${ }^{117}$ Instruction for envoys, Liw, August 16, 1784, BPAU 8322, sheet 599. See M. Roguski, op. cit., pp. 359-360.

${ }_{118}$ Instruction for envoys, Liw, August 19, 1782, BPAU 8322, sheet 593v; J. Michalski, Sejmiki poselskie..., part 3, p. 476; J. Włodarczyk, op. cit., p. 214. ${ }^{119}$ Instruction for envoys, Liw, August 16, 1784, BPAU 8322, sheet 598v. 
The land of Liw was consistent in raising objection to new taxes that could be burdensome for the nobility, and which could be imposed by the Sejm $(1780,1784)^{120}$. The nobility wanted to economise by reducing the number of treasure officials by half, and by diverting the salaries of absent commissars to the treasury (1782-1784). This showed the lack of understanding for the financing of civilian purposes ${ }^{121}$.

The sejmik of Liw showed keen interest in the way the judiciary was organised and the way it operated. Similarly to what happened in other Mazovian lands, a demand was made that the time when the cases from the Mazovian regestr were tried in the Crown Tribunal should be changed or extended $(1786)^{122}$. In light of the bill from 1775 the cases from this regestr were to be tried from the beginning of December to the end of January (every two years). The allocated time was considered too short and unfavourable for the reason of the Piotrkow deputies' departure for Christmas vacation ${ }^{123}$. The sejmik of Liw also demanded that the term of the local court of the land should be changed (moved to Monday, 1782, 1784) ) $^{124}$. It was one of the few local postulates that were fulfilled at the 'free' sejms in the times of the Permanent Council. In 1786 the Sejm enacted the project Odmiana kadencyi sadów ziemskich czerskich i liwskich [Alteration of the Term of the Courts in the Lands of Liw and Czersk] submitted by an envoy and iudex of Liw, I. Cieciszowski ${ }^{125}$ (though the postulate was missing from the Liw instruction from that year). As for other issues connected with the judiciary power, the noblemen of Liw were interested in matters related to inheritance $(1784,1786)^{126}$.

${ }^{120}$ Instructions for envoys, Liw, August 21, 1780 and August 16, 1784, BPAU 8322 , sheets $585 \mathrm{v}, 598 \mathrm{v}$.

${ }^{121}$ Instruction for envoys, Liw, August 19, 1782, BPAU 8322, sheets 591v-592; J. Michalski, Sejmiki poselskie..., part 3, p. 471.

122 Instructions for envoys, Liw, August 16, 1784 and August 21, 1786, BPAU 8322, sheets 598v, 600v-601. See W. Filipczak, Sejmiki ziemi nurskiej..., p. 54; idem, Sejmiki ziemi zakroczymskiej..., p. 116.

${ }^{123}$ Vol. leg., vol. VIII, p. 107. Trybunał Koronny; W. Filipczak, Sejmiki ziemi czerskiej..., p. 169.

${ }^{124}$ Instructions for envoys, Liw, August 19, 1782, August 16, 1784, BPAU 8322, sheets 593, 598v.

${ }^{125}$ I. Cieciszowski, Odmiana kadencyi sądow ziemskich czerskich i liwskich (project, the manuscript with the signatures of submitter and marshal of the sejm), AGAD, ZP 27, sheet 63; text of the bill: Vol. leg., vol. IX, p. 39; W. Filipczak, Sejmiki ziemi czerskiej..., pp. 170-171.

${ }^{126}$ Instruction for envoys, Liw, August 16, 1784 and August 21, 1786, BPAU 8322 , sheets $598,601 \mathrm{v}$. For the interest that the sejmiks showed in this problem 
The sejmik of Liw (just like that of Nur) demanded in 1782 that the Constitution from 1576 should be upheld. The same went for the Mazovian excepts (1577) which guaranteed distinctive legal status to the principality of Mazovia ${ }^{127}$.

As far as church issues are concerned, the sejmik of Liw postulated the approval of foundation $(1780,1784)$ for the communitarian priests on the Crown and Lithuanian territories. The postulate resulted from their merits in education (in Węgrów of Podlachia on the border of Mazovia). The sejmik also claimed that the Sejm should approve the funds owned by the convent of the Marian Fathers in Skorrzec near Siedlce $(1782,1784)^{128}$. The sejmik dealt with the situation of schools run by the communitarians in Węgrów demanding that they should be financed by the Educational Commission ${ }^{129}$. This was connected with the fact that the young noblemen had to seek education in Wegrow, because there were no schools in the lands of Liw and Nur ${ }^{130}$. The nobles expected a compensation for the heirs of Józef Załuski because of the costs borne by the bishop of Kiev while establishing a public library $(1780,1782,1786)^{131}$.

By way of conclusion I would like to describe the sejmik elites of Liw and the specificity of the procedure at the local sejmiks. Four pre-sejm sejmiks took place in the years 1780-1786. The laudaand instructions for envoys were signed by the marshal and the assessors (signing the instructions by assessors was not a regular thing on the territory of the Crown ${ }^{132}$ ). The resolutions that were typical for economic sejmiks were approved twice $(1780,1782)$; however, they were approved on the day of the envoys' proceedings, which differed from the usual course of things specified by the law. A similar situation was noticed

see J. Michalski, Reforma sadownictwa na sejmie konwokacyjnym 1764 roku, [in:] Miedzy wielka polityka a szlacheckim partykularzem. Studia z dziejów nowożytnej Polski i Europy ku czci Profesora Jacka Staszewskiego, Toruń 1993, pp. 306-307.

${ }^{127}$ Instruction for envoys, Liw, August 19, 1782, BPAU 8322, sheets 592-592v;

W. Filipczak, Sejmiki ziemi nurskiej..., p. 54. See also A. Moniuszko, op. cit., pp. 12-13.

${ }^{128}$ Instructions for envoys, Liw, August 21, 1780, August 19, 1782 and August

16, 1784, BPAU 8322, sheets 586v, 593v, 598v; M. Roguski, op. cit., p. 359.

129 Instruction for envoys, Liw, August 21, 1786, BPAU 8322, sheet 601v.

${ }^{130}$ Instruction for envoys, Liw, August 19, 1782, BPAU 8322, sheet 593v. See W. Filipczak, Sejmiki ziemi nurskiej..., p. 56.

${ }^{131}$ Instructions for envoys, Liw, August 21, 1780, August 19, 1782 and August 21, 1786, BPAU 8322, sheets 585, 592v, 601; W. Filipczak, Sejm 1778..., p. 125.

132 J. Siemiński, Organizacya sejmiku ziemi dobrzyńskiej, Kraków 1906, p. 11.

See W. Bednaruk, Sejmiki lubelskie w okresie stanisławowskim (1764-1794), Lublin 2011, p. 168. 
in the voivodship of Płock in the sejmiks that elected their deputies ${ }^{133}$. In 1780 economic issues were handled in the pre-sejm laudum. Two years later there were two separate resolutions, but they were signed by the same people (neither the new marshal nor assessors were chosen ${ }^{134}$. Also in August 1777 at the economic gathering which took place (illegally) after the election of the candidates for the office of succamerarius, the laudum was signed by the persons performing their functions at the previous sejmik, though only two assessors out of four signed $\mathrm{it}^{135}$. In connection with this the duties performed in 1780 and 1782 respectively are treated as the performance of one function per year in my compilation of the statistical data below. It can be noticed that the course of things in the land of Liw is compatible with A. Lityński's conception of the sejmik as a uniform legal institution ${ }^{136}$. The preserved sources do not contain any information on the economic sejmiks that would be held after the sejmiks electing the envoys in 1784 and 1786. The same goes for the land of Wizna; there is no information available on the self-government activity after $1782^{137}$. The sejmiks electing candidates for judiciary offices were not held in the land of Liw in the years 1780-1786. Two other sejmiks gathered instead (they elected notarius and succamerarius) in 1777. Further two sejmiks (which also elected notarius and succamerarius) gathered in the years 1787-1788. In 1777 the sejmiks were summoned by the castellan of Liw, I. Cieszkowski ${ }^{138}$. A decade later the voivode of Mazovia, Antoni Małachowski, issued both universals ${ }^{139}$. The

${ }^{133}$ A. Lityński, op. cit., p. 80.

${ }^{134}$ Lauda of the sejmiks, Liw, August 19, 1782, BPAU 8322, sheets 590, 594. See A. Lityński, Organy kierujace obradami sejmików 1764-1794 (na przykładzie sejmików województwa płockiego), [in:] Z dziejów prawa Rzeczypospolitej Polskiej, ed. A. Lityński, Katowice 1991, p. 78.

${ }^{135}$ Lauda of the sejmiks, Liw, August 21, 1777, BPAU 8322, sheets 577, $579 \mathrm{v}$.

${ }^{136}$ A. Lityński, Z problematyki klasyfikacji sejmików ziemskich, 'Prace Naukowe Uniwersytetu Śląskiego w Katowicach', Prace Prawnicze 1, 1969, pp. 96-99.

${ }_{137}$ W. Filipczak, Sejmiki ziemi wiskiej 1780-1786, [in:] Sic erat in votis. Studia i szkice ofiarowane Profesorowi Zbigniewowi Anusikowi w sześćdziesiata rocznice urodzin. Rzeczpospolita w czasach nowożytnych, eds M. Karkocha, P. Robak, Łódź 2017 , p. 344.

${ }^{138}$ Lauda of the sejmiks, Liw, August 21, and November 6, 1777, BPAU 8322, sheets 576,580 .

${ }^{139}$ Lauda of the sejmiks, Liw, February 16, 1787 and August 16, 1788, BPAU 8322 , sheets 603, 604 . 
difference of the applied procedure may have been due to the fact that in 1777 the voivode of Mazovia, Paweł Mostowski, was residing $\operatorname{abroad}^{140}$.

People in charge of the sejmiks in the land of Liw in the years $1780-1786$

\begin{tabular}{|c|c|c|c|}
\hline $\begin{array}{c}\text { Date } \\
\text { of the } \\
\text { sejmik }\end{array}$ & $\begin{array}{l}\text { Initiator of } \\
\text { proceedings }\end{array}$ & $\begin{array}{l}\text { Marshal of the } \\
\text { sejmik }\end{array}$ & Assessors \\
\hline \multirow[t]{6}{*}{$\begin{array}{l}\text { August } \\
21,1780\end{array}$} & $\begin{array}{l}\text { Krzysztof } \\
\text { Cieszkowski, } \\
\text { castellan of Liw }\end{array}$ & $\begin{array}{l}\text { Jan } \\
\text { Michałowski, } \\
\text { burgrabius of Liw }\end{array}$ & $\begin{array}{l}\text { Adam Gałecki, } \\
\text { burgrabius of Liw }\end{array}$ \\
\hline & & & $\begin{array}{l}\text { Jakub Roguski, } \\
\text { burgrabius of Liw }\end{array}$ \\
\hline & & & $\begin{array}{l}\text { Marcin Polakowski, } \\
\text { susceptans castrensis } \\
\text { of Liw }\end{array}$ \\
\hline & & & $\begin{array}{l}\text { Łukasz Polkowski, } \\
\text { susceptans castrensis } \\
\text { of Liw }\end{array}$ \\
\hline & & & Aleksander Gradowski \\
\hline & & & Ignacy Gołaski \\
\hline \multirow[t]{5}{*}{$\begin{array}{l}\text { August } \\
19,1782\end{array}$} & $\begin{array}{l}\text { Krzysztof } \\
\text { Cieszkowski, } \\
\text { castellan of Liw }\end{array}$ & $\begin{array}{l}\text { Józef } \\
\text { Grzybowski, } \\
\text { succamerarius } \\
\text { of Liw }\end{array}$ & $\begin{array}{l}\text { Jan Michałowski, } \\
\text { burgrabius of Liw }\end{array}$ \\
\hline & & & $\begin{array}{l}\text { Jan Bełdowski, } \\
\text { burgrabius of Liw }\end{array}$ \\
\hline & & & $\begin{array}{l}\text { Franciszek Radzikowski, } \\
\text { burgrabius of Liw }\end{array}$ \\
\hline & & & $\begin{array}{l}\text { Łukasz Polkowski, } \\
\text { susceptans castrensis } \\
\text { of Liw }\end{array}$ \\
\hline & & & $\begin{array}{l}\text { Balcer (Baltazar) } \\
\text { Cieszkowski, dapifer } \\
\text { of Liw's son }\end{array}$ \\
\hline
\end{tabular}

${ }^{140}$ W. Konopczyński, Mostowski Paweł, [in:] PSB, vol. XXII, 1977, pp. 68-71. See W. Filipczak, Sejmiki ziemi nurskiej..., p. 26. 


\begin{tabular}{|l|l|l|l|}
\hline & & & Michał Mroczek \\
\hline $\begin{array}{l}\text { August } \\
1684\end{array}$ & $\begin{array}{l}\text { Krzysztof } \\
\text { Cieszkowski, } \\
\text { castellan of Liw }\end{array}$ & $\begin{array}{l}\text { Lukasz } \\
\text { Polkowski, } \\
\text { burgrabius } \\
\text { of Liw }\end{array}$ & $\begin{array}{l}\text { Grzegorz Strupiechowski, } \\
\text { burgrabius of Liw }\end{array}$ \\
\hline & & & Antoni Zaliwski \\
\hline & & & Aleksander Gradowski \\
\hline $\begin{array}{l}\text { August } 1,1786 \\
\text { Grzybowski, } \\
\text { succamerarius of Liw }\end{array}$ & $\begin{array}{l}\text { Strupiechowski, } \\
\text { burgrabius of Liw }\end{array}$ & $\begin{array}{l}\text { Jacek Cieciszowski, } \\
\text { iudex of Liw's son }\end{array}$ \\
\hline & & & Ignacy Gołaski \\
\hline & & & $\begin{array}{l}\text { Jan Jaczewski, notarius } \\
\text { of Liw's son }\end{array}$ \\
\hline & & & Antoni Rozwadowski \\
\hline & & & Tomasz Roguski \\
\hline
\end{tabular}

Sources: Lauda and instructions for envoys, Liw August 21, 1780, August 19, 1782, August 16, 1784, August 21, 1786, BPAU 8322, sheets 582-601v.

The sejmiks that elected envoys in the years 1780-1784 were opened by the castellan of Liw, K. Cieszkowski ${ }^{141}$. In August 1777 the proceedings connected with the choice of succamerarius were initiated by I. Cieszkowski, who was K. Cieszkowski predecessor in the office ${ }^{142}$. In 1786 the pre-sejm sejmik was launched by succamerarius of Liw Stanisław Grzybowski, who had earlier played the same role in November $1777^{143}$ (soon after taking up his office). In the years 1780-1786 the function of the marshal of the sejmik was performed by a different person on each occasion (see Table 1). Burgrabius J. Michałowski, the 'director' in 1780, was elected the sejmik's candidate for the office of notarius terrestris (twice, i.e. in 1777 and 1787) and the office of subiudex (1789) ${ }^{144}$. Two years after he had performed the marshal's function he was entrusted with

${ }^{141}$ Minutes of the Permanent Council, July 28, 1778, AGAD, ML VII, No. 20, p. 201; M. Roguski, op. cit., p. 379.

${ }^{142}$ Laudum of the sejmik, Liw, August 21, 1777, BPAU 8322, sheet 576v.

${ }^{143}$ Lauda of the sejmiks, Liw, November 6, 1777 and August 21, 1786, BPAU 8322 , sheets 580,600 .

${ }^{144}$ Lauda of the sejmiks, Liw, November 6, 1777 and February16, 1787, BPAU 8322, sheets 580v, 603v; L. Zalewski, Szlachta ziemi..., p. 55. 
assessor's duties. J. Grzybowski, the son of succamerarius of Liw, became an envoy to the second term of the Great Sejm in 1790 when he was a subdapifer ${ }^{145}$. . Polkowski, who was in charge of the proceedings in 1784, had been an assessor at the two former pre-sejm sejmiks. Also, the next marshal (in 1786), burgrabius G. Strupiechowski, had performed assessor's duties two years before. In 1789 he became the sejmik's candidate for the position of subiudex of $\mathrm{Liw}^{146}$. In the analysed period the marshals of sejmiks had a rather low position (three of them performed the function of burgrabius castrensis); none of them was in charge of the higher office of his land.

Six assessors, or sometimes four, were customarily elected at the sejmik in Liw (August 1777, 1784, February 1787) ${ }^{147}$. In the years 17801786 this function was performed by many members from untitled nobility, but in the earlier period there had been some officials from the land of Liw, who were sometimes highly-ranked. At the sejmik electing envoys in 1778 people in charge included dapifer Michał Cieszkowski, pincerna Michał Buyno, notarius terrestris and castrensis A. Jaczewski, and custos thesauri S. Zambrzycki ${ }^{148}$. Jaczewski and Zambrzycki were later elected envoys (more on that soon), while M. Cieszkowski was a vexilliferwhen he opened the sejmik in the course of which he became a candidate for the office of succamerarius ${ }^{149}$. In the period under analysis the function of assessor was performed more than once by: susceptans Łukasz Polkowski (1780, 1782), Aleksander Gradowski (1780, 1784), Ignacy Gołaski $(1780,1786)$ and Antoni Rozwadowski (1784, 1786). In addition, Golaski was an assessor during the pre-sejm debate in 1778, while A. Rozwadowski performed that function in February $1787^{150}$. As for the noblemen who assisted the marshal just once in the years 1780-1786, numerous activists performed that function slightly earlier or later. In August 1777 the role of assessor was played by J. Roguski, to be taken over by A. Gałecki, M. Polkowski

${ }^{145}$ W. Szczygielski, Referendum trzeciomajowe..., p. 144; L. Zalewski, Szlachta ziemi..., p. 57; M. Roguski, op. cit., pp. 358-359.

${ }^{146}$ L. Zalewski, Szlachta ziemi..., p. 55.

${ }^{147}$ Lauda of the sejmiks, Liw, August 21, 1777, August 16, 1784 and February 16, 1787, BPAU 8322, sheets 576v, 597, 603.

${ }^{148}$ Laudum and instruction for envoys, Liw, August 17, 1778, AGAD, ZP 125, sheet 223v.

${ }^{149}$ Laudum of the sejmik, Liw, August 16, 1788, BPAU 8322, sheets 604-604v.

${ }^{150}$ Lauda of the sejmiks, Liw, August 17, 1778 and February 16, 1787, AGAD, ZP 125, sheets 223v, 225; and AGAD, ML IX, No. 94, p. 256. 
and M. Mroczek in November of that year ${ }^{151}$. After 1786 the function of assessor was taken up again by B. Cieszkowski, the vexillifer's son (1787, 1788), J. Jaczewski, the notarius' son, and I. Dąbrowski (1788). Later on, the noblemen who became marshals of the sejmiks included former assessors (from 1782 and 1786), that is, iudex's son, J. Cieciszowski (1787), and burgrabius F. Radzikowski (1788) ${ }^{152}$. In February 1787 F. Radzikowski was elected the sejmik's candidate for the office of notarius terrestris, and in 1789 he became the candidate for the office of subiudex, which he actually gained ${ }^{153}$. F. Radzikowski performed the function of the marshal during the sejmik of Liw on February 8, $1790^{154}$.

Table 2

Envoys to the Sejm from the Land of Liw in the years 1780-1786

\begin{tabular}{|c|l|}
\hline $\begin{array}{c}\text { Date of the } \\
\text { sejmik }\end{array}$ & \multicolumn{1}{c|}{ The envoys elected in Liw } \\
\hline August 21, 1780 & $\begin{array}{l}\text { Szczepan Zambrzycki, venator of Liw; Florian Cieszkowski, } \\
\text { capitaneus of Kleszczele }\end{array}$ \\
\hline August 19, 1782 & $\begin{array}{l}\text { Ignacy Cieciszowski, iudex terrestris of Liw; Stanisław } \\
\text { Ossolinski, capitaneus of Liw's son }\end{array}$ \\
\hline August 16, 1784 & $\begin{array}{l}\text { Ignacy Cieciszowski, iudex terrestris of Liw; Antoni } \\
\text { Jaczewski, notarius terrestris and castrensis of Liw }\end{array}$ \\
\hline August 21, 1786 & $\begin{array}{l}\text { Ignacy Cieciszowski, iudex terrestris of Liw; Szczepan } \\
\text { Zambrzycki, pincerna of Liw }\end{array}$ \\
\hline
\end{tabular}

Sources: Lauda and instructions for envoys, Liw, August 21, 1780, August 19, 1782, August 16, 1784, August 21, 1786, BPAU 8322, sheets 582-601v.

Eight envoys' mandates that the sejmik of Liw was in possession of in the years 1780-1786 went to five persons (see Table 2). In the analysed period judge I. Cieciszowski, who had also been an envoy in $1776^{155}$, performed this function three times. In 1787

${ }^{151}$ Lauda of the sejmiks, Liw, August 22, and November 6, 1777, BPAU 8322, sheets 576v, 580v; L. Zalewski, Szlachta ziemi..., pp. 52-53.

${ }^{152}$ Lauda of the sejmiks, Liw, February 16, 1787 and August 16, 1788, BPAU 8322, sheets 603, 604v; L. Zalewski, Szlachta ziemi..., p. 54.

${ }^{153}$ Laudum of the sejmik, Liw, February 16, 1787, AGAD, ML IX, No. 94, p. 256;

L. Zalewski, Szlachta ziemi..., p. 55.

${ }^{154}$ M. Roguski, op. cit., p. 382.

${ }^{155}$ Instruction for the envoys, Liw, July 15, 1776, AGAD, ZP 125, sheet 89. 
I. Cieciszowski opened the sejmik that elected a notarius, while in 1788 he was elected a candidate for the office of succamerarius (and finally took up that post) ${ }^{156}$. S. Zambrzycki, who was an envoy from Liw twice, had been the marshal in $1776^{157}$. F. Cieszkowski was elected an envoy in 1780 and received the envoy's mandate again in November $1790^{158}$. A. Jaczewski, notarius terrestris and castrensis since 1777 , became an envoy in 1784 , but probably died in January 1787, because the universal summoning noblemen to election at the sejmik was issued in February of that year ${ }^{159}$.

In the period under analysis the land of Liw was dominated by the royalist party. The major roles in that party were played by the Cieszkowski family (including castellan Krzysztof) and the Cieciszowski family whose member, Ignacy, iudex terrestris (and succamerarius since 1788), became the leader as the most efficient parliamentary activist of his land in the eighties of the $18^{\text {th }}$ century. His position had certainly been strengthened due to the influence of his brother, Adam, who had been in charge of Stanisław August's private chancellery in the years 1780-1783. Even after the death of the Crown notarius, I. Cieciszowski's position was not shaken. After the Constitution of the $3^{\text {rd }}$ of May had been accepted, the current succamerarius of Liw was the main figure of the patriotic party in his land, and met the king's requirements concerning the support of the nobility for the Government Act ${ }^{160}$. Another person who became very active in the parliamentary activities in the analysed period was Szczepan Zambrzycki, who had made a spectacular career as an official in the land of Liw (he was also iudex castrensis of Warsaw, which offered huge opportunities). In $1776 \mathrm{~S}$. Zambrzycki performed the function of the marshal of the sejmik as a treasurer. Subsequently, he climbed the hierarchy ladder to access the rank of the dapifer of Liw ${ }^{161}$. The less conspicuous person in the years 1780-1786 was Onufry Oborski, an envoy to the Great Sejm (elected in 1788), a candidate

${ }^{156}$ Lauda of the sejmiks, Liw, February 16, 1787 and August 16, 1788, BPAU 8322, sheets 603, 604v; M. Danilewiczowa, Cieciszowski Ignacy..., p. 38.

${ }^{157}$ Instruction for envoys, Liw, July 15, 1776, AGAD, ZP 125, sheet 91.

${ }^{158}$ L. Zalewski, Szlachta ziemi..., p. 57; M. Roguski, op. cit., p. 358.

${ }^{159}$ Laudum of the sejmik, Liw, February 16, 1787, AGAD, ML IX, No. 94, p. 255.

160 W. Szczygielski, Referendum trzeciomajowe..., p. 148, pp. 162-163.

${ }^{161}$ Instruction for envoys, Liw, July 15, 1776, AGAD, ZP 125, sheet 91; L. Zalewski, Szlachta ziemi..., p. 76. 
for the office of succamerarius in August 1788 (as a subdapifer), and finally, the iudex terrestris of Liw ${ }^{162}$.

No serious influence of the magnates' opposition can be seen in the land of Liw in the analysed period. The allusion to the bishop Soltyk affair in the instruction for envoys from 1782 should be regarded as a minor occurrence. The royalists' confidence during the sejmiks is reflected in the fact that in 1778 and 1788 the candidates for the envoys elected there included the three successive heads of the king's private chancellery (J. Ogrodzki and A. Cieciszowski in 1778; Pius Kiciński in 1788) ${ }^{163}$.

Translated by Dorota Filipczak

\section{Bibliography}

\section{Archival sources}

Archiwum Główne Akt Dawnych w Warszawie [AGAD]

(The Central Archives of Historical Records in Warsaw)

Archiwum Publiczne Potockich / Public Archives of the Potocki Family, No. 313, vol. XI.

Metryka Litewska / The Lithuanian Metrica, section VII, No. 20; section IX, No. 94.

Sieradzkie grodzkie, relacyjne / The books of Sieradz castle, accounts No. 160, 168.

Zakroczymskie grodzkie, relacje / The books of Zakroczym castle, accounts No. 79,81 .

Zbiór Popielów / The Popiel Collection, No. 108, 125, 126, 128, 132.

Biblioteka Książąt Czartoryskich w Krakowie [BCz]

(The Princes Czartoryski Library in Cracow)

manuscripts 655, 663, 666, 669, 673, 686, 695, 724, 803.

${ }^{162}$ W. Szczygielski, Oborski Onufry..., pp. 450-451; M. Roguski, op. cit., pp. 360-361, p. 378.

${ }^{163}$ M. Rymszyna, op. cit., pp. 114-115; J. Michalski, Kiciński Pius, [in:] PSB, vol. XII, Wrocław 1966, p. 384; W. Filipczak, Sejm 1778..., p. 74. For the contribution of P. Kicinski to the Great Sejm see R. Butterwick, Faworyt - demagog? Pius Kicinski na Sejmie Czteroletnim, [in:] Faworyci i opozycjoniści. Król a elity polityczne $w$ Rzeczypospolitej XV-XVIII w., eds M. Markiewicz, R. Skowron, Kraków 2006, pp. 486-492; W. Szczygielski, Sejm Wielki (1788-1792). Studium z dziejów łagodnej rewolucji, Łódź 2015, pp. 125-131. 
Biblioteka Naukowa PAU i PAN w Krakowie [BPAU]

(The Science Library of the PAAS and the PAS in Cracow)

manuscript 8322.

\section{Printed sources}

Dyaryusz Seymu wolnego ordynaryinego... 1782..., ed. P. Kiciński, Warszawa 1782.

Dyaryusz Seymu wolnego ordynaryinego... 1784..., ed. M. Tukalski-Nielubowicz, Warszawa 1785.

Volumina legum, vol. VII-VIII, ed. J. Ohryzko, Petersburg 1860; vol. IX, Kraków 1889.

\section{STudies}

Bałtruszajtys G., Sadownictwo Komisji Skarbowych $w$ sprawach handlowych i przemysłowych (1764-1794), Warszawa 1977.

Bednaruk W., Sejmiki lubelskie $w$ okresie stanisławowskim (1764-1794), Lublin 2011.

Borkowska-Bagieńska E., Zbiór praw sądowych Andrzeja Zamoyskiego, Poznań 1986.

Butterwick R., Faworyt - demagog? Pius Kiciński na Sejmie Czteroletnim, [in:] Faworyci $i$ opozycjoniści. Król a elity polityczne $w$ Rzeczypospolitej XV-XVIII $w$., eds M. Markiewicz, R. Skowron, Kraków 2006, pp. 485-492.

Choińska-Mika J., Mazowiecki parlamentaryzm XVI-XVIII wieku, [in:] Dzieje Mazowsza lata 1527-1794, vol. II, ed. J. Tyszkiewicz, Pułtusk 2015, pp. 115-165.

Choińska-Mika J., Sejmiki mazowieckie w dobie Wazów, Warszawa 1998.

Czeppe M., Kamaryla Pana z Dukli. Kształtowanie się obozu politycznego Jerzego Augusta Mniszcha 1750-1763, Warszawa 1998.

Czeppe M., Sołtyk Kajetan, [in:] Polski słownik biograficzny, vol. XL, WarszawaKraków 2001, pp. 387-404.

Danilczyk A., Afera Dogrumowej a konsolidacja opozycji antykrólewskiej w latach 1785-1786, 'Kwartalnik Historyczny' 2004, vol. CXI, No. 4, pp. 47-81.

Danilczyk A., W kręu afery Dogrumowej. Sejm 1786 roku, Warszawa 2010.

Danilewiczowa M., Cieciszowski Adam, [in:] Polski słownik biograficzny, vol. IV, Kraków 1938, pp. 37-38.

Danilewiczowa M., Cieciszowski Ignacy, [in:] Polski słownik biograficzny, vol. IV, Kraków 1938, p. 38.

Deputaci Trybunału Koronnego 1578-1794. Spis, part 5 (1751-1794), ed. J. Ternes, Warszawa 2017.

Dukwicz D., Rosja wobec sejmu rozbiorowego warszawskiego (1772-1775), Warszawa 2015. 
Dygdała J., Raczyński Kazimierz, [in:] Polski słownik biograficzny, vol. XXIX, Wrocław 1986, pp. 644-653.

Dzięgielewski A., Życie polityczne na Mazowszu od schyłku XV do połowy XVII wieku, [in:] Dzieje Mazowsza lata 1527-1794, vol. II, ed. J. Tyszkiewicz, Pułtusk 2015, pp. 29-113.

Filipczak W., Sejm 1778 roku, Warszawa 2000.

Filipczak W., Sejmiki województwa płockiego 1780-1786, 'Przegląd Nauk Historycznych' 2009, vol. VIII, No. 2, pp. 23-62.

Filipczak W., Sejmiki ziemi czerskiej 1780-1786, 'Przegląd Nauk Historycznych' 2010, vol. IX, No. 1, pp. 139-179.

Filipczak W., Sejmiki ziemi nurskiej 1780-1786, 'Przegląd Nauk Historycznych' 2014, vol. XIII, No. 1, pp. 23-62.

Filipczak W., Sejmiki ziemi wiskiej 1780-1786, [in:] Sic erat in votis. Studia i szkice ofiarowane Profesorowi Zbigniewowi Anusikowi w sześćdziesiata rocznice urodzin. Rzeczpospolita w czasach nowożytnych, eds M. Karkocha, P. Robak, Łódź 2017, pp. 321-350.

Filipczak W., Sejmiki ziemi zakroczymskiej 1778-1786, 'Przegląd Nauk Historycznych' 2015, vol. XIV, No. 2, pp. 85-121.

Filipczak W., Szlachta koronna wobec reformy sejmu $w$ świetle instrukcji poselskich $z$ lat 1778-1786, [in:] Między Barokiem a Oświeceniem. Parlamentaryzm, eds B. Krysztopa-Czupryńska, J. Kiełbik, Olsztyn 2016, pp. 55-69.

Filipczak W., Życie sejmikowe prowincji wielkopolskiej w latach 1780-1786, Łódź 2012.

Gierowski J.A., Sejmik generalny księstwa mazowieckiego na tle ustroju sejmikowego Mazowsza, Wrocław 1948.

Konopczyński W., Mostowski Pawet, [in:] Polski słownik biograficzny, vol. XXII, Wrocław 1977, pp. 68-71.

Lityński A., Organy kierujące obradami sejmików 1764-1794 (na przykładzie sejmików województwa płockiego), [in:] Z dziejów prawa Rzeczypospolitej Polskiej, ed. A. Lityński, Katowice 1991, pp. 63-87.

Lityński A., Sejmiki województwa płockiego przed i w czasie Sejmu Czteroletniego. $Z$ badań nad organizacja i funkcjonowaniem, [in:] W dwusetna rocznice wolnego Sejmu. Ludzie - państwo - prawo czasów Sejmu Czteroletniego, ed. A. Lityński, Katowice 1988, pp. 76-108.

Lityński A., Z problematyki klasyfikacji sejmików ziemskich, 'Prace Naukowe Uniwersytetu Śląskiego w Katowicach', Prace Prawnicze 1, 1969, pp. 89-105.

Mazowsze $w$ drugiej połowie XVI wieku (Atlas Historyczny Polski), part 2, ed. W. Pałucki, Warszawa 1973.

Michalski J., Kiciński Pius, [in:] Polski słownik biograficzny, vol. XII, Wrocław 1966, pp. 383-385.

Michalski J., Ogrodzki Jacek, [in:] Polski słownik biograficzny, vol. XXIII, Wrocław 1978, pp. 648-651. 
Michalski J., Reforma sadownictwa na sejmie konwokacyjnym 1764 roku, [in:] Między wielka polityka a szlacheckim partykularzem. Studia z dziejów nowożytnej Polski i Europy ku czci Profesora Jacka Staszewskiego, Toruń 1993, pp. 295-313.

Michalski J., Sejm w czasach panowania Stanisława Augusta, [in:] Historia sejmu polskiego, vol. I, ed. J. Michalski, Warszawa 1984, pp. 350-419.

Michalski J., Sejmiki poselskie 1788 roku, part 2-3, 'Przegląd Historyczny' 1960, vol. LI, No. 2-3, pp. 331-365, 465-477.

Moniuszko A., Mazowieckie sady ziemskie (1588-1648). Organizacja-funkcjonowanie - postepowanie, Warszawa 2013.

Pieńkowska A., Pieńkowski M.A., Sejmiki mazowieckie wobec problemów wewnętrznych Rzeczypospolitej w latach 1661-1665, Oświęcim 2015.

Ratajczyk L., Przezwyciężenie kryzysu militarnego Polski przed reformami Sejmu Czteroletniego, Warszawa 1975.

Roguski, M., Udział drobnej szlachty w sejmikach, konfederacjach izgromadzeniach ziemi liwskiej $w$ latach 1765-1795, [in:] Po unii - sejmiki szlacheckie w Rzeczypospolitej XVI-XVIII wieku, eds H. Lulewicz, M. Wagner, Siedlce 2013, pp. 357-391.

Rostworowski E., Sprawa aukcji wojska na tle sytuacji politycznej przed Sejmem Czteroletnim, Warszawa 1957.

Rudnicki K., Biskup Kajetan Sołtyk 1715-1788, Kraków-Warszawa 1906.

Rymszyna M., Gabinet Stanisława Augusta, Warszawa 1962.

Siemieński J., Organizacya sejmiku ziemi dobrzyńskiej, Kraków 1906.

Stanek W., Konfederacja sejmowa z 1776 roku - narzędzie dworskiego zamachu stanu, 'Acta Universitatis Nicolai Copernici' 1993, Historia XXVIII. Nauki Humanistyczno-Społeczne, issue 259, pp. 135-147.

Stroynowski A., Opozycja sejmowa $w$ dobie rząów Rady Nieustajacej. Studium $z$ dziejów kultury politycznej, Łódź 2005.

Stroynowski A., Zmiany sytuacji politycznej $w$ Rzeczypospolitej przed ostatnim 'wolnym' sejmem w 1786 r., 'Acta Universitatis Lodziensis', Folia Historica 58, 1996, pp. 83-102.

Sucheni-Grabowska A., O sejmiku ziemi liwskiej 1542-1695, [in:] Między Wschodem a Zachodem. Rzeczpospolita XVI-XVIII w. Studia ofiarowane Zbigniewowi Wójcikowi $w$ siedemdziesiąta rocznice urodzin, ed. T. Chynczewska-Hennel et al., Warszawa 1993, pp. 29-38.

Szczygielski W., Krasinski Kazimierz, [in:] Polski słownik biograficzny, vol. XV, Wrocław 1970, pp. 184-186.

Szczygielski W., Oborski Onufry, [in:] Polski słownik biograficzny, vol. XXIII, Wrocław 1978, pp. 450-451.

Szczygielski W., Referendum trzeciomajowe. Sejmiki lutowe 1792 roku, Łódź 1994.

Szczygielski W., Sejm Wielki (1788-1792). Studium z dziejów łagodnej rewolucji, Łódź 2015.

Szwaciński T., Sejmiki poselskie przed konwokacja 1764 r., 'Kwartalnik Historyczny' 2006, vol. CXIII, No. 1, pp. 19-56. 
Urwanowicz J., Polityczna aktywność szlachty mazowieckiej w latach 1669-1793, [in:] Dzieje Mazowsza lata 1527-1794, vol. II, ed. J. Tyszkiewicz, Pułtusk 2015, pp. 539-599.

Urzędnicy centralni $i$ nadworni koronni Polski XIV-XVIII wieku. Spisy, penned by K. Chłapowski, S. Ciara, Ł. Kądziela, T. Nowakowski, E. Opaliński, G. Rutkowska, T. Zielińska, ed. A. Gąsiorowski, Kórnik 1992.

Wagner M., Sejmik ziemi liwskiej w dobie Jana III Sobieskiego (1674-1696). Zarys problematyki, [in:] Po unii - sejmiki szlacheckie $w$ Rzeczypospolitej XVI-XVIII wieku, eds H. Lulewicz, M. Wagner, Siedlce 2013, pp. 253-262.

Włodarczyk J., Sejmiki łęczyckie, Łódź 1973.

Zakrzewski A.B., Sejmiki Wielkiego Księstwa Litewskiego XVI-XVIII w. Ustrój i funkcjonowanie: sejmik trocki, Warszawa 2000.

Zalewski L., Szlachta ziemi liwskiej. Sejmiki, urzędy, herbarz, Warszawa 2005.

Zalewski L., Ziemia liwska, ludzie, miejscowości, wydarzenia, Warszawa 2002.

Zielińska Z., 'O sukcesyi tronu w Polszcze’ 1787-1790, Warszawa 1991.

Zielińska Z., Poniatowski Michał Jerzy, [in:] Polski słownik biograficzny, vol. XXVII, Wrocław 1983, pp. 455-471.

Zielińska Z., Sejmiki 8 lutego 1790 - pierwsze referendum na temat dokonań sejmu, 'Wiek Oświecenia' 1993, vol. IX, pp. 114-137.

Zwierzykowski M., Komisja Skarbowa Poznańska. Z dziejów sejmikowej administracji $i$ sadownictwa skarbowego $w$ Wielkopolsce $w$ XVII $i$ XVIII wieku, Poznań 2003.

WitOLD FILIPCZAK

\title{
Sejmiki ziemi liwskiej 1780-1786
}

\begin{abstract}
A rtykuł dotyczy sejmików ziemi liwskiej wchodzącej w skład województwa mazowieckiego. W latach 1780-1786 szlachta na obradach w Liwie wybierała posłów na sejm, a także rozstrzygała problemy o charakterze samorządowym. W tekście przedstawione zostały przygotowania do sejmików, ich przebieg oraz podjęte uchwały. Ziemia liwska była zdominowana przez stronnictwo regalistyczne, w którym czołowe role odgrywały rodziny Cieszkowskich i Cieciszowskich. Najaktywniejszym parlamentarzysta był sędzia ziemski liwski Ignacy Cieciszowski, który w latach 1780-1786 trzykrotnie był wybierany posłem na sejm. Na jego pozycję wpłynęło wsparcie brata Adama, w okresie 1780-1783 kierujacego Gabinetem Stanisława Augusta. Związki liderów miejscowej szlachty ze stronnictwem regalistycznym nie miały dużego wpływu na treść instrukcji poselskich, natomiast znajdowały wyraz w działalności reprezentantów ziemi liwskiej w parlamencie.
\end{abstract}

Słowa kluczowe: ziemia liwska, sejmiki, parlamentaryzm, Mazowsze w XVIII wieku. 